\title{
КЛІНІКО-ЕКОНОМІЧНА ЕФЕКТИВНІСТЬ ЗАСТОСУВАННЯ КАМФОРНОї ОЛІЇ ПРИ ДЕРМАТИТІ, АСОЦІЙОВАНОМУ 3 НЕТРИМАННЯМ
}

\author{
ДВНЗ «Тернопільський державний медичний університет \\ імені І. Я. Горбачевського МОЗ України», м. Тернопіль, Україна
}

\begin{abstract}
Мета: дослідити клініко-економічну ефективність камфорної олії у лікуванні дерматиту, асоційованого 3 нетриманням.

Матеріали і методи. У перспективне спостережне дослідження увійшли 134 дорослі пацієнти з дерматитом, асоційованим із нетриманням. У дослідній групі $(\mathrm{n}=104)$ для очищення і захисту шкіри використовували камсрорну олію. У групі контролю (n=30) застосовували вологі серветки 3 в 1 або комбінацію піни для очищення шкіри та захисного крему. Середній вік пацієнтів становив (77士11) років (діапазон 36-92, 3 них 83 (61,9 \%) жінок. У всіх пацієнтів було наявне нетримання сечі, яке поєднувалося з нетриманням калу в 48 (35,8 \%) осіб. Зразки змивів шкіри висіювали на середовище Сабуро для грибів і культивували 48-72 год при температурі $37^{\circ} \mathrm{C}$ до виділення Candida spp. Статистичну обробку результатів виконували за допомогою програмного забезпечення Міcrosoft Excel® 2016 та MedCalc $®$. Зміну показників вважали достовірною при рівні значущості не менше 0,05 (p<0,05). Порівняння між показниками груп проводили за допомогою регресійного аналізу з визначенням відношення шансів при 95 \% довірчому інтервалі.
\end{abstract}

Результати. Через один місяць використання досліджуваного препарату відбулося достовірне зменшення числа осіб із категорією GLOBIAD 2B з $30(28,8 \%)$ до $16(15,4 \%)$ пацієнтів $\left(\chi^{2}=22,1 ; p<0,001\right)$ та збільшення чисельності категорії 1A 329 (27,9 \%) до 52 (50,0 \%) пацієнтів ( $X^{2}=21,04 ;$ p<0,001). Грибковоподібний висип спостерігали на початковому візиті в 53 (51,0 \%) хворих, який, після курсу лікування, достовірно зменшився і визначали у 33 (31,7 \%) осіб $\left(\chi^{2}=16,4 ; p<0,001\right)$. Діагноз був підтверджений мікологічно у $30(28,8 \%)$ досліджуваних, а після курсу лікування лише у $8(7,8 \%)$ хворих $\left(x^{2}=20,05 ; p<0,001\right)$. Економічний аналіз показав, що одна процедура догляду за шкірою за допомогою камфорної олії коштувала 0,65 грн, тоді як у групі контролю на рутинні засоби витрачали 1,65 грн.

Висновки. Місцеве застосування камсрорної олії призвело до достовірного покращення клінічного перебігу захворювання, зменшення кількості випадків грибковоподібного висипу, зниження частоти колонізації шкіри Candida spp., а також виявилось економічно вигідним порівняно з рутинними засобами догляду за шкірою в осіб із дерматитом, асоційованим з нетриманням.

КЛЮЧОВІ СЛОВА: дерматит, асоційований з нетриманням; камфорна олія.

Дерматит, асоційований з нетриманням (ДАН), $€$ переважаючим ураженням шкіри в осіб із нетриманням сечі та/або калу [4]. Профрілактика і лікування ДАН $є$ важливою складовою частиною в забезпеченні надання якісного медичного догляду в пацієнтів із нетриманням, значну частину яких становлять особи похилого віку. Недостатня кількість проведених порівняльних наукових досліджень щодо якості, ефрективності та економічної вигідності засобів для очищення і захисту шкіри від забруднення випорожненнями ускладнює видання стандартизованих рекомендацій 3 ведення ДАН. Розпізнавання захворювання та диференціювання його з іншими ураженнями шкіри, зокрема з пролежнями, додатково ускладнює ведення пацієнтів у клінічній практиці $[2,7]$.

Наявність сечі та фрекалій на денудованій шкірі створює сприятливе середовище для розвитку грибкової, найчастіше кандидозної, інфеекції. Проте залишається нез'ясованим, чи нетримання сприяє підвищеній кандидозній колонізації, та чи, навпаки,

(๖) І. Й. Когут, С. О. Галникіна, 2018 нетримання виступає тригером для розвитку кандидозної інсрекції уже колонізованої шкіри [6].

Бактеріальне інфікування шкіри не пов'язують з ДАН, тоді як клінічні ознаки інфрікування Candida albicans, відповідно до візуального огляду кандидозного висипу, спостерігають на перинеальній та перигенітальній шкірі в 18-32 \% пацієнтів, що підтверджується мікробіологічним дослідженням у 75 \% таких випадків [6]. За даними J. Campbell et al., ріст Candida spp. спостерігають у пацієнтів із нетриманням у $43 \%$ випадків у періанальній ділянці та в $24 \%$ - у пахових складках, тоді як в осіб без нетримання, відповідно, в 28 та $14 \%$ [6]. Кандидозна індекція при ДАН проявляється в основному макулопапульозним висипом, вкритим білими пастоподібними виділеннями, 3 характерним сателітним розсіюванням по периферії, поширюючись на здорову шкіру [6].

У догляді за шкірою при нетриманні дотримуються трьох послідовних етапів: очищення, зволоження і захисту, для цього використовують відповідні окремі або комбіновані засоби. Важливо 
зауважити, що на практиці для профрілактики і для лікування ДАН використовують однакові засоби і процедури [4]. Доцільно надавати перевагу використанню комбінованих полікомпонентних засобів із догляду за шкірою, коли в одному виробі поєднано очисні, зволожувальні, захисні й антисептичні компоненти, наприклад вологі серветки 3 в 1. Проте полікомпонентність комбінованих виробів може підвищити ризик побічних місцевих реакцій і збільшує вартість лікування. Bliss et al. підрахували, що вартість застосування бар'єрного крему, без врахування затрат на роботу персоналу та супутніх витрат, може коштувати 0,22-025 \$ на добу, тоді як застосування захисної акрилатної термополімерної плівки, яку наносять один раз на 3 дні, здешевлює витрату на препарат у середньому до 0,04 \$ на один епізод нетримання, але вказана вартість не враховує витрати на кількаразове щоденне очищення. При використанні згаданих бар'єрних засобів разом із засобом для очищення витрати на догляд за шкірою зростають відповідно до 0,27-0,33 і 0,12 \$ [8]. Крім того, нанесення захисних акрилатних термополімерних плівок протипоказане на гіперемійованих та інфікованих ділянках, що обмежує їх використання у хворих із ДАН.

У 2015 р. глобальною експертною групою сформульовано загальні характеристики ідеального засобу для профрілактики і лікування ДАН, який має бути клінічно ефективним та економічно вигідним, не проявляти подразнювальної дії, поєднуватися з іншими топічними засобами, мати прозорий вигляд, легко витиратися з поверхні шкіри для її огляду та бути зручним у використанні [3]. За додатковими показаннями до лікувальної програми ДАН приєднують протигрибкові препарати, топічні стероїдні протизапальні та антибактеріальні засоби, засоби для поглинання та утримання випорожнень [4].

У процесі пошуку клінічно ефективного та економічно вигідного офіцинального засобу для догляду за шкірою у хворих на ДАН було зроблено припущення, що монокомпонентний препарат «Камфорна олія» може замінити полікомпонентні комбінації. До уваги було взято те, що камфора має місцеву протизапальну, антисептичну, протигрибкову, відволікаючу, знеболювальну дії, усуває свербіж та має дезодоруючий еорект [5], а соняшникова олія - пом'якшувальні, зволожувальні, захисні, протизапальні властивості, сприяє відновленню ліпідної мантії на сухих і мацерованих ділянках, зменшує трансепідермальну втрату води, покращує бар'єрний захист поверхні шкіри від агресивної дії сечі та калу, стимулює проліферацію кератиноцитів [1]. За рахунок гідрофообних властивостей олії досягається її очищувальний ефект. Загальновідомо, що місцеве використання камфрорної олії у загальноприйнятих дозах $€$ безпечним та не становить ризику при регламентованому використанні [5].

Мета роботи: дослідити клініко-економічну ефективність камфрорної олії у лікуванні ДАН.

Матеріали і методи. У дане ретроспективне статистичне дослідження увійшли 134 дорослі пацієнти з ДАН, які перебували на тривалому стаціонарному догляді у Петриківському обласному геріатричному пансіонаті у період з липня 2014 до жовтня 2015 р. Дослідну групу склали 104 хвоpi, у яких для забезпечення очищення і захисту шкіри від дії сечі та калу використовували препарат для зовнішнього застосування «Камфорна олія» (камфрора рацемічна 0,1 г у 1 мл олії соняшникової). У групі контролю (n=30) застосовували рутинні місцеві гігієнічні засоби для догляду за шкірою при нетриманні, а саме вологі серветки 3 в 1 або комбінацію піни для очищення шкіри та захисного крему. Середній вік пацієнтів становив (77士11) років (діапазон 36-92), з них 83 (61,9\%) жінок. У всіх пацієнтів було наявне нетримання сечі, яке поєднувалося 3 нетриманням калу в 48 (35,8 \%) осіб. Порівнянню підлягали показники, визначені перед початком лікування та через один місяць курсу лікування.

Основними критеріями для віднесення пацієнтів до 1 категорії GLOBIAD було постійне почервоніння шкіри, а до 2 категорії - ерозування везикул і пухирів та екскоріації. Критеріями для віднесення хворих до підкатегорії В були такі ознаки інфікування шкіри, як біле лущення, наліт на дні рани, надмірна або гнійна ексудація. Пацієнти, які не увійшли до підкатегорії $\mathrm{B}$, були класифріковані як підкатегорія А.

Попередній діагноз ДАН встановлювали за наявності еритеми 3 або без інших характерних уражень внаслідок контакту із сечею та/або калом в осіб з нетриманням на періанальній шкірі, сідницях, геніталіях, внизу живота, внутрішніх та задніх поверхнях стегон, у складках між сідницями чи між геніталіями та стегнами.

Грибковоподібний висип визначали переважно по периферії вогнища ДАН у вигляді гіперемійованих плям або папул, вкритих білим нальотом, а також пустул, ерозій, мацерації та набряку.

Забір матеріалу на мікологічне дослідження проводили 3 грибковоподібних висипів, а за їх відсутності - з пахової ділянки, у перший день дослідження та через один місяць після лікування. Зразки змивів висіювали на середовище Сабуро для грибів і культивували 48-72 год при температурі $37^{\circ} \mathrm{C}$.

Створення первинної бази даних і статистичну обробку результатів виконували за допомогою програмного забезпечення Microsoft Excel® 2016 та MedCalc®. Для аналізу категорійних показників (результати мікологічного посіву, кількість випадків грибковоподібного висипу і категорій GLOBIAD) проводили біваріантний 
аналіз за допомогою визначення хі-квадрат у тесті McNemar для біномних категорій. Статистичну значущість було встановлено на рівні $\alpha=0,05$ зі ступенем свободи df=1. Зміну показників вважали достовірною при рівні значущості не менше $0,05$ ( $<<0,05)$. Порівняння між показниками груп проводили за допомогою регресійного аналізу для визначення відношення шансів (OR) при $95 \%$ довірчому інтервалі (Cl 95 \%).

Результати дослідження та їх обговорення. Клінічна характеристика груп

У дослідну групу, на початку спостереження, до 1А категорії увійшли 29 (27,9 \%) хворих, до $1 \mathrm{~B}-23$ (22,1 \%), до 2А - 22 (21,6 \%) і до 2В $30(28,8 \%)$ пацієнтів. Через один місяць лікування досліджуваним препаратом відбулося достовірне зменшення числа осіб із категорією 2В до $16(15,4 \%)$ пацієнтів $\left(\chi^{2}=22,1 ; p<0,001\right)$ та збільшення чисельності категорії 1 А до 52 (50,0 \%) пацієнтів $\left(\chi^{2}=21,04 ;\right.$ p<0,001) (табл. 1).

У групу контролю, на початку спостереження, до 1А категорії увійшли 13 (43,3 \%) хворих, до 1В 2 (6,7 \%), до 2 A - $5(16,7 \%)$ і до 2B - $10(33,3 \%)$ пацієнтів. Через один місяць лікування досліджуваним препаратом також відбулося достовірне зменшення числа осіб із категорією 2В до $3(10,0 \%)$ пацієнтів $\left(\chi^{2}=5,44 ; p=0,020\right)$ та збільшення чисельності категорії 1 А до 18 (60,0 \%) пацієнтів ( $\left.\chi^{2}=5,00 ; p<0,025\right)$ (табл. 2).

Таблиця 1. Чисельність пацієнтів дослідної групи за категоріями GLOBIAD

\begin{tabular}{|c|c|c|c|c|}
\hline \multirow{2}{*}{ Категорія } & Початковий візит & Кінцевий візит & \multirow{2}{*}{$\chi^{2}$} & $\mathrm{p}$ \\
\cline { 2 - 3 } & $\mathrm{N}(\%)$ & $\mathrm{N}(\%)$ & 21,04 & $<0,001$ \\
\hline 1А & $29(27,9)$ & $52(50,0)$ & 1,79 & 0,181 \\
\hline 1B & $23(22,1)$ & $17(16,3)$ & 0,19 & 0,663 \\
\hline 2A & $22(21,6)$ & $19(18,3)$ & 12,07 & $<0,001$ \\
\hline 2B & $30(28,8)$ & $16(15,4)$ & \\
\hline
\end{tabular}

Таблиця 2. Чисельність пацієнтів групи контролю за категоріями GLOBIAD

\begin{tabular}{|c|c|c|c|c|}
\hline \multirow{2}{*}{ Категорія } & Початковий візит & Кінцевий візит & \multirow{2}{*}{$\chi^{2}$} & $\mathrm{p}$ \\
\cline { 2 - 3 } & $\mathrm{N}(\%)$ & $\mathrm{N}(\%)$ & 5,00 & 0,025 \\
\hline 1A & $13(43,3)$ & $18(60,0)$ & 0,00 & 1,000 \\
\hline 1B & $2(6,7)$ & $2(6,7)$ & 0,50 & 0,480 \\
\hline 2A & $5(16,7)$ & $7(23,3)$ & 5,44 & 0,020 \\
\hline 2B & $10(33,3)$ & $3(10,0)$ & & \\
\hline
\end{tabular}

Грибковоподібний висип спостерігали на початковому візиті в 53 (51,0 \%) хворих, який, після курсу лікування, достовірно зменшився і визначали у $33(31,7 \%)$ осіб $\left(\chi^{2}=16,4 ; p<0,001\right)$. У групі контролю показники, відповідно, достовірно знизились 3 $12(40,0 \%)$ до $5(16,7 \%)$ хворих $\left(\chi^{2}=5,4 ; p<0,02\right)$.

Мікробіологічна характеристика груп

За допомогою мікологічного посіву Candida spp. була виявлена у 39 (37,5 \%) хворих дослідної групи та 11 (36,7 \%) пацієнтів контролю. Через один місяць лікування відбулося достовірне зниження випадків колонізації, яка була відмічена, відповідно, у 12 (11,5 \%) хворих дослідної групи $\left(\chi^{2}=24,04 ;\right.$ p<0,001) та в $6(20,0 \%)$ пацієнтів контролю $\left(\chi^{2}=5,00 ; p<0,025\right)$.

Грибковоподібний висип був підтверджений мікологічно у 30 (28,8 \%) досліджуваних, а після курсу лікування лише у 8 (7,8 \%) хворих, що 3 високою достовірністю вказувало на зниження показника під дією лікування $\left(\chi^{2}=20,05 ; p<0,001\right)$. У групі контролю кількість мікологічно підтвердженого висипу достовірно знизилась 38 (26,7 \%) до 4 (13,3 \%) випадків $\left(\chi^{2}=4,0 ; p=0,046\right)$.

Також після курсу лікування було виявлено статистично достовірний зв'язок між подвійним нетриманням та контамінацією поверхні шкіри
Candida spp. як у дослідній $\left(\chi^{2}=21,4 ; p<0,001\right)$, так і в контрольній $\left(\chi^{2}=8,0 ; p=<0,005\right)$ групах.

Економічна характеристика досліджуваних засобів

Економічний аналіз показав, що на одну процедуру догляду за шкірою, після випадку нетри-

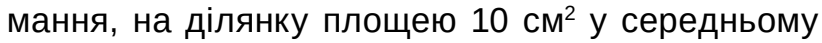
витрачали 1 мл камфорної олії та 2 марлеві серветки. Зважаючи на те, що 1 мл камфорної олії коштує 0,09 грн, а 1 марлева серветка - 0,28грн, загальна вартість витрат на матеріали становила 0,65 грн на одну маніпуляцію. У групі контролю на одну процедуру обробки шкіри витрачали 2 вологі серветки 3 в 1, що коштувало 1,65 грн, або застосовували поєднання очищаючої пінки та захисного крему, на нанесення яких витрачали 3 марлеві серветки, що також коштувало 1,65 грн за одну процедуру догляду (табл. 3).

Обговорення результатів

Внаслідок місцевого використання олійного розчину камфрори рацемічної для забезпечення догляду за шкірою, ураженою ДАН, покращився перебіг хвороби за рахунок достовірного зменшення кількості випадків категорії 2В та збільшення числа пацієнтів з категорією 1A за GLOBIAD, a також до високодостовірного зниження частоти 
Таблиця 3. Розрахунок вартості засобів для догляду за шкірою при ДАН

\begin{tabular}{|l|c|c|c|c|}
\hline \multicolumn{1}{|c|}{ Засоби } & $\begin{array}{c}\text { Каморорна } \\
\text { олія }\end{array}$ & $\begin{array}{c}\text { Вологі } \\
\text { серветки 3 в 1 }\end{array}$ & $\begin{array}{c}\text { Пінка } \\
\text { Seni Care }\end{array}$ & $\begin{array}{c}\text { 3ахисний крем } \\
\text { Seni Care }\end{array}$ \\
\hline Об'єм упаковки & 50 мл & 48 шт & 500 мл & 200 мл \\
\hline Вартість (грн) & 4,5 & 79 & 123 & 112 \\
\hline $\begin{array}{l}\text { Розхід на одне протирання ділянки } \\
\text { площею 10 см² }\end{array}$ & 1 мл & 1 шт & 1 мл & 1 мл \\
\hline $\begin{array}{l}\text { Вартість продукту на одне протирання } \\
\text { ділянки 10 см (грн) }\end{array}$ & $4,5 / 50 \times 1=0,09$ & $79 / 48 \times 1=1,65$ & $123 / 500 \times 1=0,25$ & $112 / 200=0,56$ \\
\hline Вартість серветки марлевої 5х5 см (грн) & 0,28 & & 0,28 & 0,28 \\
\hline Витрата серветок на протирання ділянки & 2 & 0 & 2 & 1 \\
\hline $\begin{array}{l}\text { Вартість розходу серветок на одну } \\
\text { ділянку (грн) }\end{array}$ & $0,28 \times 2=0,56$ & 0 & $0,28 \times 2=0,56$ & $0,28 \times 1$ \\
\hline $\begin{array}{l}\text { Вартість обробки однієї ділянки } \\
\text { (продукт + серветки) (грн) }\end{array}$ & $0,09+0,56=$ \\
\end{tabular}

колонізації Candida spp. та зменшення кількості випадків грибковоподібного висипу.

У цьому дослідженні частота грибковоподібного висипу була вищою за частоту кандидозної колонізації, тому що не всі випадки з клінічними проявами грибкового ураження підтверджувалися за допомогою мікологічного дослідження, а саме на початковому візиті позитивні результати мікологічних посівів на Candida spp. були отримані у 30 353 (56,6 \%) хворих із грибковоподібним висипом у дослідній групі та в 8 з 12 (66,7 \%) таких пацієнтів групи контролю, а дослідна і контрольна групи статистично не відрізнялися між собою (OR 1.53; $95 \% \mathrm{Cl} 0.41$ to 5.73; p=0.525). Після завершення курсу лікування позитивні мікологічні посіви на Candida spp. були виявлені у 8333 (24,2 \%) пацієнтів із грибковоподібним висипом у дослідній групі та в 4 з 5 (80,0 \%) таких хворих контролю. Таке зниження числа випадків грибковоподібного висипу, підтвердженого мікологічним аналізом на Candida spp. після курсу лікування у дослідній групі виявилося достовірно більшим порівняно 3 групою контролю (OR 12.5; 95 \% Cl 1.21 to 128.67; p=0.034), що можна пояснити додатковою топічною протигрибковою дією каморори.

Використання камфорної олії виявилося у 2,5 раза дешевше, ніж застосування вологих серветок 3 в 1 або поєднання очищаючої пінки та захисного крему, що заощаджувало по 1 грн на кожній маніпуляції. Враховуючи, що пацієнт потребує проведення догляду за шкірою не менше 3 разів на добу, економія коштів склала 90 грн на місяць на одного пацієнта.

\section{Висновки}

У цьому дослідженні вперше вивчено ефективність застосування каморорної олії у лікуванні пацієнтів із ДАН. Застосування досліджуваного препарату призвело до достовірного покращення клінічного перебігу захворювання, зменшення кількості випадків грибковоподібного висипу, зниження частоти колонізації шкіри Candida spp., а також виявилось економічно вигідним порівняно з рутинними засобами догляду за шкірою в осіб із ДАН.

Перспективи подальших досліджень полягають у вивченні ефекту від впровадження препарату в клінічну практику.

\section{Список літератури}

1. Candida albicans colonisation, continence status and incontinence-associated dermatitis in the acute care setting: a pilot study / J. Campbell, F. Coyer, A. Mudge [et al.] // Int. Wound J. - 2017. - 14. - P. 488-495.

2. Camphor induces cold and warm sensations with increases in skin and muscle blood flow in human / T. Kotaka, S. Kimura, M. Kashiwayanagi, J. Iwamoto // Biol. Pharm. Bull. - 2014. - Vol. 37. - P. 1913-1918.

3. CONSIDER - Core Outcome Set in IAD Research: study protocol for establishing a core set of outcomes and measurements in incontinence-associated dermatitis research / K. Van den Bussche, D. De Meyer, N. Van Damme [et al.] // J. Adv. Nurs. - 2017. - Vol. 73. - P. 2473-2483.

4. Effectiveness of topical skin products in the treatment and prevention of incontinence-associated dermatitis: a systematic review / P. Pather, S. Hines, K. Kynoch, F. Coyer // JBI Database System Rev. Implement. Rep. - 2017. - Vol. 15. P. 1473-1496.

5. Interventions for preventing and treating incontinence-associated dermatitis in adults / D. Beeckman, N. Van Damme, L. Schoonhoven [et al.] // Cochrane Database of Systematic Reviews. - 2016. - No. 11. - CD011627.

6. Natural oils for skin-barrier repair: Ancient compounds now backed by modern science / A. R. Vaughn, A. K. Clark, R. K. Sivamani, V. Y. Shi // Am. J. Clin. Dermatol. - 2018. - Vol. 19. - P. 103-117.

7. Proceedings of the Global IAD Expert Panel. Incontinence associated dermatitis: moving prevention forward/D. Beeckman, J. Campbell, D. Chimentro [et al.] // Wounds International. -2015. - 24 p. Mode access : www.woundsinternational.com.

8. Woo K. Health economic benefits of cyanoacrylate skin protectants in the management of superficial skin lesions I K. Woo // International Wound Journal. - 2014. - Vol. 11. - P. 431-437. 
References

1. Beeckman, D., Campbell, J., \& Chimentro, D. (2015). Proceedings of the Global IAD Expert Panel. Incontinence associated dermatitis: moving prevention forward. Wounds International. Retrieved from: www.woundsinternational.com. 2. Beeckman, D., Van Damme, N., Schoonhoven, L., Van Lancker, A., Kottner, J., Beele, H., et al. (2016). Interventions for preventing and treating incontinence-associated dermatitis in adults. Cochrane Database of Systematic Reviews, 11 , CD011627.

3. Campbell, J., Coyer, F., Mudge, A., Robertson, I., \& Osborne, S. (2017). Candida albicans colonisation, continence status and incontinence-associated dermatitis in the acute care setting: a pilot study. Int. Wound J., 14, 488-495.

4. Kotaka, T., Kimura, S., Kashiwayanagi, M., \& Iwamoto, J. (2014). Camphor induces cold and warm sensations with increases in skin and muscle blood flow in human. Biol. Pharm. Bull., 37, 1913-1918.

5. Pather, P., Hines, S., Kynoch, K., \& Coyer, F. (2017). Effectiveness of topical skin products in the treatment and prevention of incontinence-associated dermatitis: a systematic review. JBI Database System Rev. Implement Rep., 15, $1473-1496$.

6. Van den Bussche, K., De Meyer, D., Van Damme, N., Kottner, J., \& Beeckman, D. (2017). CONSIDER - Core Outcome Set in IAD Research: study protocol for establishing a core set of outcomes and measurements in incontinence-associated dermatitis research. J. Adv. Nurs., 73, 2473-2483.

7. Vaughn, A.R., Clark, A.K., Sivamani, R.K., \& Shi, V.Y. (2018). Natural oils for skin-barrier repair: ancient compounds now backed by modern science. Am. J. Clin. Dermatol., 19, 103-117.

8. Woo, K. (2014). Health economic benefits of cyanoacrylate skin protectants in the management of superficial skin lesions. International Wound Journal, 11, 431-437.

\section{КЛИНИКО-ЭКОНОМИЧЕСКАЯ ЭФФЕКТИВНОСТЬ ПРИМЕНЕНИЯ КАМФОРНОГО МАСЛА ПРИ ДЕРМАТИТЕ, АССОЦИИРОВАННОМ С НЕДЕРЖАНИЕМ}

И. И. Когут, С. А. Галныкина

ГВУЗ «Тернопольский государственный медицинский университет имени И. Я. Горбачевского МЗ Украины»,

г. Тернополь, Украина

Цель: исследовать клинико-экономическую эффрективность камфорного масла в лечении дерматита, ассоциированного с недержанием.

Материалы и методы. В перспективное наблюдательное исследование вошли 134 взрослые пациенты с дерматитом, ассоциированным с недержанием. В исследуемой группе (n=104) для очистки и защиты кожи использовали камфорное масло. В группе контроля $(n=30)$ применяли влажные салфетки 3 в 1 или комбинацию пены для очистки кожи и защитного крема. Средний возраст пациентов составил (77士11) лет (диапазон 36-92), из них 83 (61,9 \%) женщин. У всех пациентов имелось недержание мочи, которое сочеталось с недержанием кала у $48(35,8$ \%) человек. Образцы смывов кожи высеивали на среду Сабуро для грибов и культивировали 48-72 ч при температуре $37^{\circ} \mathrm{C}$ до выделения Candida spp. Статистическую обработку результатов выполняли с помощью программного обеспечения Microsoft Excel® 2016 и MedCalc ${ }^{\circledR}$. Изменение показателей считали достоверным при уровне значимости не менее 0,05 $(p<0,05)$. Сравнение между показателями групп проводили с помощью регрессионного анализа с определением отношения шансов при 95 \% доверительном интервале.

Результаты. Через один месяц использования исследуемого препарата произошло достоверное уменьшение числа лиц с категорией GLOBIAD 2B из $30(28,8 \%)$ до $16(15,4 \%)$ пациентов $\left(\chi^{2}=22,1 ; p<0,001\right)$ и увеличение численности категории 1А с $29(27,9 \%)$ до $52(50,0 \%)$ пациентов $\left(X^{2}=21,04 ; p<0,001\right)$. Грибковоподобная сыпь наблюдалась на начальном визите в 53 (51,0\%) больных, которая, после курса лечения, достоверно уменьшился и определялась в $33(31,7 \%)$ случаях $\left(X^{2}=16,4 ; p<0,001\right)$. Диагноз был подтвержден микологически в 30 (28,8 \%) больных, а после курса лечения только у $8(7,8 \%)$ лиц $\left(\chi^{2}=20,05\right.$; $\mathrm{p}<0,001)$. Экономический анализ показал, что одна процедура ухода за кожей с помощью камфорного масла стоила 0,65 грн, тогда как в группе контроля на рутинные средства уходило 1,65 грн.

Выводы. Местное применение камфорного масла привело к достоверному улучшению клинического течения заболевания, уменьшению количества случаев грибковоподобных высыпаний, снижению частоты колонизации кожи Candida spp., а также оказалось экономически выгодным по сравнению с рутинными средствами ухода за кожей у лиц с дерматитом, ассоциированным с недержанием.

КЛЮЧЕВЫЕ СЛОВА: дерматит, ассоциированный с недержанием; камфорное масло.

\section{CLINICAL AND ECONOMICAL EFFICIENCY OF CAMPHORATED OIL IN INCONTINENCE ASSOCIATED DERMATITIS}

I. Y. Kohut, S. O. Galnykina

I. Horbachevsky Ternopil State Medical University, Ternopil, Ukraine

Purpose: to investigate the clinical and economic efficiency of camphorated oil in the treatment of incontinence associated dermatitis.

Materials and Methods. A prospective observational study included 134 adult patients with incontinence associated dermatitis. In the study group $(n=104)$ camphorated oil was used for cleansing and protecting the skin. 
In the control group $(n=30)$, wet wipes 3 in 1 or a combination of cleansing foam and protective cream were used. The average age of patients was (77 \pm 11$)$ (ranged 36-92) years, of whom $83(61.9 \%)$ were women. All patients were urinary incontinent while 48 residents $(35.8 \%)$ had double urinary and faecal incontinence. Mycological swab specimens were cultured directly on Sabouraud's medium for yeasts and incubated at $37^{\circ}$ Celsius for 48-72 hours to identify Candida spp. Statistical data were analysed using the Microsoft Excel ${ }^{\circledR} 2016$ and MedCalc ${ }^{\circledR}$ software. The change was considered reliable at a level of significance not less than $0.05(p<0.05)$. The comparison between the groups was performed using regression analysis to determine the odds ratio at $95 \%$ confidence interval.

Results. The significant decrease was revealed in the number of patients with GLOBIAD category $2 \mathrm{~B}$ from $30(28.8 \%)$ to $16(15.4 \%)$ patients $\left(X^{2}=22.1 ; p<0.001\right)$ and a significant increase in the size of category $1 \mathrm{~A}$ from $29(27.9 \%)$ to $52(50.0 \%)$ patients $\left(X^{2}=12.07 ; p<0.001\right)$ after 1 month period of the study of drug application. Fungal rash was observed at the initial visit in 53 (51.0\%) of the studied patients, who, after the course of treatment, decreased significantly and was determined in $33(31.7 \%)$ patients $\left(x^{2}=16.4 ; p<0.001\right)$. Fungal rash was confirmed mycologically in $30(28.8 \%)$ patients, and after treatment only in $8(7.8 \%)$ patients $\left(X^{2}=20.05 ; p<0.001\right)$. An economic analysis showed that one procedure of skin care by camphorated oil cost UAH 0.65 , whereas, in the control group $1.65 \mathrm{UAH}$ was spent for routine treatment.

Conclusions. Topical use of camphorated oil decreased the severity of the disease, reduced fungal appearing rash and Candida spp. colonisation, and was cost saving comparatively to routine skin care products in incontinence associated dermatitis.

KEY WORDS: incontinence associated dermatitis; camphorated oil.

Рукопис надійшов до редакції 26.11.2018 p.

\section{Відомості про авторів:}

Когут Ігор Йосипович - лікар-дерматовенеролог, здобувач кафедри інфекційних хвороб з епідеміологією, шкірними та венеричними хворобами ДВНЗ «Тернопільський державний медичний університет імені І. Я. Горбачевського МОЗ України»; тел.: +38(067) 991-31-32.

Галникіна Світлана Олександрівна - доктор медичних наук, професор кафедри інфекційних хвороб з епідеміологією, шкірними та венеричними хворобами ДВНЗ «Тернопільський державний медичний університет імені І. Я. Горбачевського МОЗ України»; тел.: +38(067) 965-38-31. 